American Journal of Geoscience 1 (1): 1-6, 2010

ISSN 1948-9846

(C) 2010 Science Publications

\title{
Capturing Biogas: A Means to Reduce Green House Gas Emissions for the Production of Crude Palm Oil
}

\author{
S. Vijaya, A.N. Ma and Y.M. Choo \\ Engineering and Processing Division, Malaysian Palm Oil Board, \\ No. 6 Persiaran Institute Bandar Baru Bangi, 43000 Kajang Selangor, Malaysia
}

\begin{abstract}
Problem statement: The Malaysian oil palm industry is an important industry to the nation. In 2009 alone the total export earnings reached RM 49.6 billion. The industry is under constant attack of its performance from the perspective of the environment, especially with regard to its Green House Gas (GHG) Emissions. Being an export orientated industry; this issue has to be tackled head on to quantify the GHG emissions of the oil palm industry. Approach: About 12 palm oil mills were selected for this gate to gate case study. Inventory data which consisted of raw material, energy usage and gaseous emissions were collected from the selected palm oil mills over a period of 3 years. A comparative study was conducted to compare the GHG emissions of the production of Crude Palm Oil (CPO) with and without allocation and biogas capture. GHG emissions from all sources are summed up and changed into units of $\mathrm{CO}_{2}$ equivalent $\left(\mathrm{CO}_{2} \mathrm{eq}\right)$ which is used to standardize GHG emissions. Results: The main parameter causing the highest contribution to the GHG emissions within this system boundary is the biogas from the anaerobic treatment of the POME. When biogas is captured, the total GHG emission drops significantly. This shows the urgency and need for the palm oil mills to capture their biogas and use it as renewable energy. Conclusion: Less than $10 \%$ of the palm oil mills capture their biogas because the palm oil mills have excess energy from their biomass itself and to invest in a large sum of money to harvest the biogas will mean that they will need the infrastructure to use or sell the harvested biogas. Currently, the industry is moving towards either harnessing biogas from POME or producing value-added products such as fertilizer from POME which avoids methane generation. This move is visible with the gradual annual increase in the number of palm oil mills capturing their biogas.
\end{abstract}

Key words: Green house gas emissions, carbon footprint, crude palm oil, oil palm industry, palm oil mill, capturing biogas

\section{INTRODUCTION}

The Malaysian oil palm industry is an important industry to the Nation. In 2009 alone the total export earnings of the oil palm industry reached 49.6 billion (Wahid, 2010). The industry faces many challenges and among them is meeting the increasing global demand for edible oil, the lingering effects of a weak global economy in 2009 and issues on sustainability and the environment. The industry is under constant attack of its performance from the perspective of the environment, especially with regard to its carbon footprint or Green House Gas (GHG) emissions. Being an export orientated industry; this issue has to be tackled head on to actually quantify the GHG of the oil palm industry.

Greenhouse gases are those gaseous constituents of the atmosphere, both natural and anthropogenic, that absorb and emit radiation at specific wavelengths within the spectrum of thermal infrared radiation emitted by the Earth's surface, the atmosphere itself and by clouds. This property causes the greenhouse effect. Water vapor $\left(\mathrm{H}_{2} \mathrm{O}\right)$, Carbon dioxide $\left(\mathrm{CO}_{2}\right)$, Nitrous oxide $\left(\mathrm{N}_{2} \mathrm{O}\right)$, methane $\left(\mathrm{CH}_{4}\right)$ and ozone $\left(\mathrm{O}_{3}\right)$ are the primary greenhouse gases in the Earth's atmosphere. Moreover, there are a number of entirely human-made greenhouse gases in the atmosphere, such as the halocarbons and other chlorine and bromine containing substances, dealt with under the Montreal Protocol. Beside $\mathrm{CO}_{2}, \mathrm{~N}_{2} \mathrm{O}$ and $\mathrm{CH}_{4}$, the Kyoto Protocol also deals with the greenhouse gases Sulphur Hexafluoride $\left(\mathrm{SF}_{6}\right)$, Hydrofluorocarbons (HFCs) and Perfluorocarbons (PFCs) (IPCC AR4 SYR, 2009). Green House Gas (GHG) emissions from all sources are summed up and changed into units of $\mathrm{CO}_{2}$ equivalent

Corresponding Author: S. Vijaya, Engineering and Processing Division, Malaysian Palm Oil Board, No. 6 Persiaran Institute Bandar Baru Bangi, 43000 Kajang Selangor, Malaysia 
$\left(\mathrm{CO}_{2}\right.$ eq) which is used to standardize GHG emissions (Altuslumen, 2009).

Greenhouse gases greatly affect the temperature of the Earth; without them, Earth's surface would be on average about $33^{\circ} \mathrm{C}$ colder than at present. The sharp acceleration in $\mathrm{CO}_{2}$ emissions since the year 2000 to more than a $3 \%$ increase per year (more than $2 \mathrm{ppm}$ per year) from $1.1 \%$ per year during the $1990 \mathrm{~s}$ is attributable to the lapse of formerly declining trends in carbon intensity of both developing and developed nations (Wikipedia, 2010).

Objective: The objectives of this study is to quantify the GHG emissions of the milling process to produce one tonne of Crude Palm Oil (CPO) at the palm oil mill and to compare the GHG emissions with and without biogas capture and allocation with by products.

\section{MATERIALS AND METHODS}

Twelve palm oil mills were selected for this case study. These palm oil mills were selected based on the type of mill which were either plantation based mills or private mills. They have different processing capacities of oil palm fresh fruit bunches ranging from 20 tonnes $\mathrm{h}^{-1}$ up till 90 tonnes $\mathrm{h}^{-1}$ and also these mills are all located at different zones in Peninsular
Malaysia basically from north, mid south, south, east and East Malaysia.

Inventory data were collected from the selected palm oil mills over a period of 3 years. They consisted of raw material and energy usage as well as GHG emissions. The study only takes into account the inputs and outputs in the milling process to produce CPO. The system boundary of the milling process is shown in Fig. 1. Using the inventory data, a Life Cycle Inventory (LCI) was created for the production of 1 tonne CPO with and without allocation as shown in Table 3 using the LCI for 1 tonne CPO, a comparative study was conducted to compare the GHG emissions of the palm oil mill:

- With biogas emissions

- With allocation with by products and biogas emissions

- With biogas capture

- With allocation with by products and biogas capture

Global warming potential: The concept of a Global Warming Potential (GWP) was developed to compare the ability of each greenhouse gas to trap heat in the atmosphere relative to another gas. The definition of a

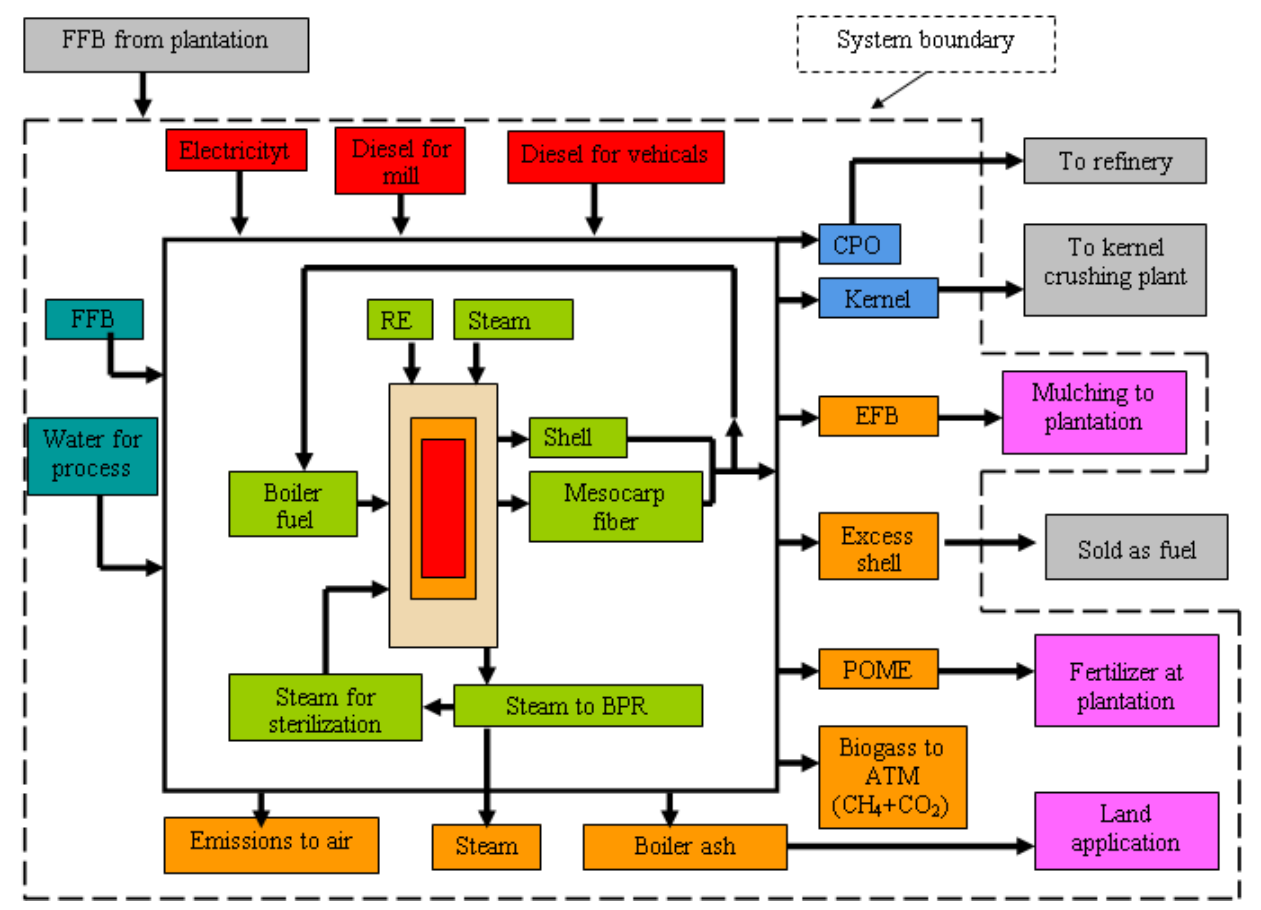

Fig. 1: Milling process. FFB: Oil palm Fresh Fruit Bunch; RE: Renewable Energy; EFB: Empty Fruit Bunch; BPR: Back Pressure Receiver Tank 
GWP for a particular greenhouse gas is the ratio of heat trapped by one unit mass of the greenhouse gas to that of one unit mass of $\mathrm{CO}_{2}$ over a specified time period (US EPA, 2010). The Global warming potentials are as shown in Table 1 which was taken from (IPCC TAR, 2007).

The GHG will be calculated using the GWP and emissions factors. The Emission factors used for diesel and electricity were taken from (Wisions Sustainable Energy Support Program SEPS, 2009) as shown in Table 2.

Allocation with by product: More often than not, a system will yield more than one product. In such cases, allocation must be made for input and output flows. Within the palm oil milling sub-system, a number of processes takes place in addition to the main process i.e., extraction of CPO from the mesocarp of sterilized palm fruits. The by-product from the milling process is palm kernel. Besides the main products comprising CPO and palm kernel, other outflows include the production of sludge or POME during the clarification step, EFB during stripping of FFB, pressed mesocarp fiber from mechanical pressing of palm fruits, nuts from the depericarping stage and lastly, shells after nut cracking to release palm kernel.

The kernels are subsequently sent to kernel crushing plants for extraction of Crude Palm Kernel Oil (CPKO). This crushing process is not accounted for in this study because CPKO extraction is considered as part of a different system which is excluded from the boundary of the present system under study. The method selected for partition of by-products was allocation based on weight. Palm kernel and palm shell are considered as a by-product. System boundary expansion is conducted for EFB and POME which are recycled in the plantation as part of fertilizer substitute.

Table 1: Global warming potentials for selected green house gasses IPCC TAR (2007)

\begin{tabular}{lc}
\hline Green House Gas (GHG) & $\begin{array}{l}\text { Global Warming Potential (GWP) } \\
\text { for 100 years }\end{array}$ \\
\hline $\mathrm{CO}_{2}$ & 1 \\
$\mathrm{CH}_{4}$ & 23 \\
$\mathrm{~N}_{2} \mathrm{O}$ & 296 \\
$\mathrm{HFC}-23$ & 12000 \\
$\mathrm{HFC}-134 \mathrm{a}$ & 1300 \\
$\mathrm{SF}_{6}$ & 22200 \\
\hline
\end{tabular}

Table 2: Emission Factors (Wisions Sustainable Energy Support Program SEPS, 2009)

\begin{tabular}{ll}
\hline Energy & Emission factors \\
\hline Diesel & $0.00268 \mathrm{t} \mathrm{CO}_{2}$ eq L \\
Electricity & $0.000594 \mathrm{t} \mathrm{CO}_{2}$ eq $\mathrm{kWh}^{-1}$ \\
\hline
\end{tabular}

The pressed mesocarp fiber and shell are burnt as fuel in the palm oil mill boiler while the excess shell is sold out to other biomass boilers. However the credits for the use of shell elsewhere are not included in this study as it is out of the system boundary and so allocation is carried out for shell.

\section{RESULTS}

This study was a gate to gate study. The starting point is at the FFB hoppers where the FFBs are received up till the production of the $\mathrm{CPO}$ in the storage tanks at the palm oil mills. All inventory data have been collected for a period of five years from each palm oil mill. Table 3 shows the Life Cycle Inventory (LCI) data for 1 tonne CPO produced at the palm oil mill. The GHG values are shown in Table 4 and 5.

Table 3:Average LCI data of 12 palm oil mills for the production of 1 tonne CPO with and without allocation

\begin{tabular}{lrr}
\hline Parameters & $\begin{array}{r}\text { Amount with } \\
\text { allocation }\end{array}$ & $\begin{array}{r}\text { Amount with } \\
\text { out allocation }\end{array}$ \\
\hline Fresh fruit bunch (t) & 3.1000 & 5.08000 \\
Power consumption from turbine (MJ) & 224.0800 & 367.35000 \\
Power consumption from grid (MJ) & 1.7600 & 2.89000 \\
Diesel consumption for mill (MJ) & 100.3300 & 164.48000 \\
Transportation of diesel to mill tkm & 0.5400 & 0.89000 \\
Fuel used in boiler & & \\
Mesocarp fiber (t) & 0.3600 & 0.59000 \\
Shell (t) & 0.0900 & 0.14000 \\
Boiler water consumption (t) & 1.5700 & 2.58000 \\
Water for process (t) & 2.1700 & 3.55000 \\
Kernel (t) & 0.4100 & 0.58000 \\
Mesocarp fiber (t) & 0.0000 & 0.06000 \\
Shell (t) & 0.2300 & 0.23000 \\
Empty fruit Bunch (t) & 0.7100 & 1.17000 \\
Palm oil mill effluent (t) & 1.8600 & 3.04000 \\
Methane gas (kg) & 22.2100 & 36.41000 \\
$\mathrm{CO}_{2}$ from POME pond (kg) & 36.0400 & 59.08000 \\
Boiler ash (t) & 0.0100 & 0.02000 \\
Steam input to turbine (t) & 1.6200 & 2.66000 \\
Steam input for sterilization (t) & 1.5600 & 2.56000 \\
Flue gas from stack & & \\
Particulate matter (kg) & 0.1200 & 0.20000 \\
$\mathrm{CO}_{(\mathrm{kg})}$ & 0.0400 & 0.07000 \\
$\mathrm{CO}_{2}(\mathrm{~kg})$ & 41.2800 & 67.68000 \\
$\mathrm{SO}_{\mathrm{x}}(\mathrm{kg})$ & 0.0006 & 0.00099 \\
$\mathrm{NO}_{\mathrm{x}}(\mathrm{kg})$ & 0.0700 & 0.11000 \\
\hline
\end{tabular}

Table 4:Comparative GHG emissions for 1 tonne CPO with biogas emissions with and without allocation

\begin{tabular}{lcc}
\hline & $\begin{array}{l}\text { GHG emissions } \\
\text { for 1 tonne CPO } \\
\text { (with allocation ) }\end{array}$ & $\begin{array}{l}\text { GHG emissions } \\
\text { for 1 tonne CPO } \\
\text { (without allocation) } \\
\mathrm{kg} \mathrm{CO}_{2} \text { eq }\end{array}$ \\
Output & 41.28 & 67.68 \\
\hline Boiler emissions & 0.29 & 0.48 \\
$\begin{array}{l}\text { Electricity from grid } \\
\text { Diesel }\end{array}$ & & \\
Mill consumption & 6.79 & 11.13 \\
Transportation of diesel to mill & 6.97 & 11.42 \\
Biogas & 546.85 & 896.48 \\
Total with & 602.18 & 987.18 \\
\hline
\end{tabular}


Table 5:Comparative GHG emissions for 1 tonne CPO with biogas capture with and without allocation

\begin{tabular}{lcc}
\hline & $\begin{array}{l}\text { GHG emissions } \\
\text { for 1 tonne CPO } \\
\text { (with allocation) } \\
\mathrm{kg} \mathrm{CO}_{2} \text { eq }\end{array}$ & $\begin{array}{l}\text { GHG emissions } \\
\text { for 1 tonne CPO } \\
\text { (without allocation) } \\
\mathrm{kg} \mathrm{CO}_{2} \text { eq }\end{array}$ \\
\hline Output & 41.28 & 67.68 \\
Boiler emissions & 0.29 & 0.48 \\
Electricity from Grid & & \\
$\begin{array}{l}\text { Diesel } \\
\text { Mill consumption }\end{array}$ & 6.79 & 11.13 \\
Transportation of diesel to mill & 6.97 & 11.42 \\
Biogas Captured (85\%) & 82.03 & 134.47 \\
Total & 137.36 & 225.18 \\
\hline
\end{tabular}

\section{DISCUSSION}

The oil palm Fresh Fruit Bunch (FFB) which have been delivered to the palm oil mills are received at the FFB hoppers and transferred into sterilization cages. These cages are rolled into the sterilization chambers. Live steam passes through these chambers for a duration of $90 \mathrm{~min}$ and this process called sterilization helps to loosen the individual fruits from the stalk or bunch. The steam also deactivates the enzymes which causes the breakdown of the oil into Free Fatty Acids (FFA). These FFA are undesirable in the palm oil. The industry tries to limit the development of FFA to less than 4\% (Pathak, 2005). Next the sterilized FFBs are sent to a stripper where the fruitlets are separated from the stalk or bunch which are now called Empty Fruit Bunch (EFB). The EFB are normally sent back to the plantations for mulching as fertilizer substitute.

The fruitlets from the stripper are then sent to a digester where they are converted into homogeneous oily mash by means of a mechanical stirring process. The digested mash is then pressed using a screw press to remove the majority of the CPO. At this point the CPO comprises of a mixture of oil, water and fruit solids which are screened on a vibrating screen to remove as much solids as possible. Then CPO is clarified in a continuous settling tank operation. The decanted CPO passes through a centrifugal purifier and desander to remove any remaining solid and then to the vacuum dryer to remove the moisture. The CPO is then pumped to storage tanks before it is sent off for export or refining at the refineries. The nuts with the pressed mesocarp fiber are separated at the fiber cyclone. The nuts are then cracked to produce kernels and shell. The kernels are shipped to kernel crushing plants to be processed into palm kernel oil while the shell and pressed mesocarp fiber are used as boiler fuel.

The main solid waste from the milling process is EFB, pressed mesocarp fiber, shell and boiler ash while the liquid waste is Palm Oil Mill Effluent (POME) which is the wastewater from the milling process. The gaseous emissions are from the boiler stack and biogas from the effluent treatment ponds. The EFB is sent back to the plantation for mulching while the POME is used for land application both as fertilizer substitute. The biogas value from the POME treatment used for this study is taken on a study by (Ma et al., 1999) with COD loadings of about $48000 \mathrm{mg} \mathrm{L}^{-1}$ which results to $28 \mathrm{~m}^{3}$ biogas per tonne POME (Ma et al., 1999). However the COD loadings in the palm oil mills vary quite highly and the emissions from the biogas will differ from mill to mill. The assumption made for this study is that the biogas emissions are $28 \mathrm{~m}^{3}$ tonne ${ }^{-1}$ POME at all the 12 palm oil mills.

The POME is an important semi-solid stream. The biological treatment of POME to reduce the BOD to $5000 \mathrm{ppm}$ for land application and below $50 \mathrm{ppm}$ for discharge to waterways results in the emissions of biogas which can be captured. This can be done by diverting the POME to digester tanks where biogas is trapped for use as fuel or flared off. The pressed mesocarp fibers and shells would have been solid waste emissions from the milling process but they serve as alternative fuel sources to fire the boilers in the palm oil mills to produce steam used for electricity generation and sterilization of FFB. EFB is used as mulch or compost to substitute fertilizer. The treated POME is also used as fertilizer substitute. The recycling of solid wastes such as mesocarp fiber and shell for use within the milling process establishes close-loops for these outputs from the palm oil mill while the EFB and POME which are recycled in the plantation are considered open-loop processes.

There are two columns of the LCI data shown in Table 3. One column is data which have been allocated and the other is data which has not been allocated. CPO is not the only product produced at the palm oil mills. The by-product of the milling process is palm kernel and palm shell. In view of this, weight allocation has been conducted to allocate part of the inputs and outputs to palm kernel and palm shell. The allocation between CPO, palm kernel and palm shell is $61-25-14 \%$.

In this study four GHG values were calculated for the palm oil mills using the LCI data collected and the emission factors as shown in Table 4 and 5. A comparative study was conducted to compare the GHG emissions of the palm oil mill:

- With biogas emissions

- With allocation with by products and biogas emissions

- With biogas capture

- With allocation with by products and biogas capture 
These GHG values are for the system boundary of the palm oil mill and do not include the use of the biogas as renewable energy. The main parameter causing the highest contribution to the GHG emissions within this system boundary is the biogas from the anaerobic treatment of the POME as shown in Table 4. The biogas emission alone accounts for about $90 \%$ of the total $\mathrm{CO}_{2}$ emissions. When biogas is captured, the total GHG emissions drops to $137.63 \mathrm{~kg} \mathrm{CO}_{2}$ eq tone ${ }^{-1}$ CPO. This shows the urgency for the palm oil mills to capture their biogas and use it as renewable energy. When allocation is conducted the GHG values are lower. This is because the environmental burden is now shared with the by products.

Although biogas from POME has great potential to be used as a renewable energy source, capturing of biogas is not actively adopted by the industry due to several issues related to costs, benefits and risk, poor logistics associated with national grid connection, feedin-tariffs, technology maturity and lack of interest from mills which are operating at a 'comfort zone' (Basri et al., 2008).

Currently less than $10 \%$ of the palm oil mills in the whole of Malaysia harvest their biogas and use it in their boilers or as an energy source for other uses. The main reason behind this is mainly due to the lack of infrastructure to channel this excess energy either to the national grid or for use in other facilities. Palm oil mills have excess energy from their biomass itself and to invest in a large sum of money to harvest the biogas will mean that they will need the infrastructure to use or sell the harvested biogas. In 2001, the Malaysian energy policy under the 8th Malaysia plan broadened the four fuel diversification policy to include renewable energy as a fifth fuel in the new five fuel strategy (World Resource Institute, 2001). In spite of this policy, the demands for this kind of renewable energy are still at the infancy stage in Malaysia.

Since the mills are already self sufficient on energy requirement, harvesting the biogas is not economically viable. In reality the palm oil mills can be seen as power stations which can supply their excess energy back to the grid. However due to the buying rate of the power utility provider Tenaga National Berhad (TNB) at 21 cents $\mathrm{kWh}^{-1}$ and the penalties imposed by TNB if the palm oil mills cannot supply to the grid as promised due to breakdown or low crop seasons, seem to discourage the millers from generating the readily available renewable energy at their mills. To overcome this problem requires involvement of many other stake holders particularly the energy sector of Malaysia. Actions to be taken include changes in policies and infrastructures to make harvesting such valuable biogas energy economically attractive for the palm oil industry. However, the "business as usual" attitude in the industry is beginning to change Currently, the industry is moving towards either harnessing biogas from POME or producing value-added products such as fertilizer from POME which avoids methane generation (Basri et al., 2008). This move is visible with the annual increase in the number of palm oil mills capturing their biogas. Increase in demands for the biomass from the palm oil mills namely, shell, EFB and pressed mesocarp fiber for use in biomass boilers and power plants due the five fuel policy are giving mills an option to use the harvested biogas as energy in their boilers and selling their displaced biomass. The CDM incentives and carbon trading are also attracting the millers to consider capturing the biogas.

\section{CONCLUSION}

In the past, more often than not environmental management was conducted more for image enhancement. However recent developments show a trend towards wanting a greener earth such that environmental demands have been transformed as marketing tools. Increasingly it has become a determining factor for use of products. In view of the current shift for higher environmental demands from customers as well as the emergence of eco labels, the need for the oil palm industry to also align itself with the current trend is no longer avoidable. This shift is vital for the Malaysian oil palm industry to remain competitive in order to increase its long-term profitability and sustainability. The oil palm industry is a self-sufficient industry generating its own energy for processing. The concept of recycling the palm oil mill by-products is not new but merely resurfaces in the light of recent economic and environmental concerns. Over the years the oil palm industry in Malaysia has always included responsible measures with regard to the environment. The utilization of the various byproducts through nutrient recycling in the fields has reduced the environmental impact paving the way towards zero-waste policy (Chan, 1999).

This gate to gate study of the production of CPO shows that the GHG emission can be significantly reduced by capturing the biogas. The good news is the industry is moving towards either harnessing biogas from POME or producing value-added products such as fertilizer from POME which avoids methane generation. This move is visible with the increase in the number of palm oil mills capturing their biogas. However this process can be accelerated with the intervention of the government by providing 
infrastructure and better tariff rates for the mills to dispose of their excess renewable energy which will be generated with the capture of the biogas.

\section{ACKNOWLEDGEMENT}

The researcher would like to thank the palm oil millers for allowing and assisting in the data collection at their palm oil mills. A special note of appreciation to the top management of Malaysian Palm Oil Board (MPOB) for their support. A note of thanks to the research assistants of MPOB for their involvement in the data collection.

\section{REFERENCES}

Altuslumen, 2009. Glossary of sustainability terminology. Altuslumen.

http://www.altuslumen.com/sustainability_terminol ogy.html

Basri, W., Y.M. Choo, W.S. Lim, S.K. Loh and M.C. Chow et al., 2008. Biogas Utilization in Palm Oil Mills. 1st Edn., Malaysian Palm Oil Board, Selangor, Malaysia, pp: 250.

Chan, K.W., 1999. Biomass Production in the Oil Palm Industry. In: Oil Palm and the Environment: A Malaysian Perspective, Singh, G., K.H. Lim, T. Leng and L.K. David (Eds.). Malaysian Oil Palm Growers’ Council, Kuala Lumpur, pp: 41-43.

IPCC AR4 SYR, 2009. User guide and access to more detailed information. IPCC. http://www.ipcc.ch/pdf/assessmentreport/ar4/syr/ar4_syr_appendix.pdf

IPCC TAR, 2007. Global warming potential. Wikipedia.

http://en.wikipedia.org/wiki/Global_warming_pote ntial
Ma, A.N., T.S. Toh and N.S. Chua, 1999. Renewable Energy from Oil Palm Industry. In: Oil Palm and the Environment: A Malaysian Perspective, Gurmit, S., K.H. Lim, T. Leng and L.K. David (Eds.). Malaysian Oil Palm Growers' Council, Kuala Lumpur, pp: 113-126.

Pathak, M.P., 2005. Quality of CPO and refining operations. Proceeding of the Chemistry and Technology Conference International Palm Oil Congress, Sept. 2005, Malaysian Palm Oil Board, Malaysia, pp: 426-427.

US EPA, 2010. High GWP Gases and Climate Change. EPA.

http://www.epa.gov/highgwp/scientific.html

Wahid, M.B., 2010. Overview of the Malaysian Oil Palm Industry 2009. MPOB. http://econ.mpob.gov.my/economy/Overview_200 9.pdf

Wikipedia, 2010. Greenhouse gas. Wikipedia. http://en.wikipedia.org/wiki/Greenhouse_gas

Wisions Sustainable Energy Support Program SEPS, 2009. Baseline calculations. Wisions. http://www.wisions.net/DownloadDateien/CO2BaselineCalculation_new.pdf

World Resource Institute, 2001. Energy policy in the 8th Malaysia plan/five fuel policy. WRI. http://projects.wri.org/sd-pamsdatabase/malaysia/energy-policy-8th-malaysiaplan-five-fuel-policy 